\title{
CUSTOMARY ARBITRATION IN NIGERIA: A REVIEW OF EXTANT JUDICIAL PARAMETERS AND THE NEED FOR PARADIGM SHIFT
}

\author{
Muhammed Mustapha Akanbi* \\ Lukman Adebisi Abdulrauf** \\ Abdulrazaq Adelodun Daibu**\%
}

\begin{abstract}
$\Gamma_{\text {wo }}$ forms of arbitration exist in present-day Nigeria; the first is

$\mathcal{L}$ indigenous to the various communities in the country and it is determined by the customs and traditions of the individual community. The second, which was imported, derives its source from the general laws and practice of England. The latter, which is arguably, alien to the culture and tradition of traditional Nigerian communities, has often been superimposed and applied by courts. The continuing subjugation of customary arbitration can be seen in the attitude of the Nigerian courts, whereby reliance is placed on the parameters of modern arbitration in the determination of a valid customary arbitration award in Nigeria. This article contends that the attitudes of courts in the determination of the binding nature of an award given under customary arbitration, using the parameters of modern arbitration, has caused considerable damage to the essence and potency of customary arbitration practice in Nigeria. In order to be authentic, it is contended that judicial development of customary arbitration, must respond to the traditions, attitudes and goals of the people whose society is under consideration. It should not be subject to a validity test by reference to orthodox arbitration or arbitration under the received English law. Consequently, the article examines the extant
\end{abstract}

* LL.B (Ife), LL.M (Lagos), Ph.D. (KCL, London), BL; Professor of Law, Department of Business Law, Faculty of Law, University of Ilorin. Nigeria e-mail: laroungbe@yahoo.co.uk

** LL.B (Zaria), LL.M, (Ilorin) BL; Lecturer, Department of Public Law, Faculty of Law, University of Ilorin, Ilorin. Nigeria e-mail: lukmanrauf@gmail.com

$* * *$ LL.B, LL.M, (Ilorin) BL; Lecturer, Department of Private and Property Law, Faculty of Law, University of Ilorin, Ilorin, Nigeria: E-mail: abdulrazaqdaibu@yahoo.com 
parameters to which the Nigerian courts subject the characteristics of customary arbitration in Nigeria. The article discusses the need for a paradigm shift in order for customary arbitration to respond to the exigencies of customs.

Keywords: Arbitration, custom, tradition, dispute resolution, English law, Nigeria.

doi: http://dx.doi.org/10.4314/jsdlp.v6i1.9

\section{INTRODUCTION}

English is English; Nigerian is Nigerian. The English are the English; so also the Nigerians are Nigerians. Theirs are theirs. Ours are ours. Theirs are not ours; ours are not theirs. ${ }^{1}$

The practice of disputes settlement using the process of arbitration is as old as the existence of the Nigerian society. ${ }^{2}$ Arbitration had existed in the various indigenous communities in Nigeria long before the advent

1 Per Niki Tobi JCA (as he then was) in Caribbean Trading \& Fiderily Corporation v. NNPC (1992) 7 NWLR (Pt. 252)161, 179.

2 Igbokwe V.C. "Law and Practice of Customary Arbitration in Nigeria: Agu V. Ikewibe and Applicable Law Issues Revisited." Journal of African law (1997) Vol. 41. No. 2, 201; Nwabueze B.O. Machinery of Justice in Nigeria (Cambridge University Press 1963) 45; Akpata E. The Nigeria Arbitration law in Focus (West African Books Publishers, Lagos, 1997) 1; Akanbi M.M. "Constitutionality of Customary Arbitration in Nigeria - An appraisal of Okpuruwu V. Okpokam" (A work in progress) 3-8; Oba A.A. "Juju Oath in Customary Arbitration and Their Legal Validity in Nigerian Courts" (2008) 52 (1) Journal of African Law 140; Adoke M.B 'Alternative Dispute Resolution: A Vehicle For resolving Disputes in Nigeria' (A paper presented at the 7th Hon. Justice J.M. Adesiyun Biennial Memorial Public Lecture 2012) 2-3; Imam I. "The Legal Regime Of Customary Arbitration In Nigeria Revisited" (2010) 3(2) Confluence Journal of Jurisprudence and International Law, Kogi State University, Anyigba 58-67; Oluduro O. "Customary Arbitration in Nigeria: History and Developments" in Kupolati T. (ed.) Current Issues in Nigerian Jurisprudence Essays in Honour of Chief Adegboyega Solomon Awomolo SAN (Renaissance law Publishers, Lagos, 2007) 3. 
of the British legal system of court litigation into the country. ${ }^{3}$ It was part of the customary norms of Nigerian society. ${ }^{4}$ Before the colonial era, customary law operated freely in its areas of influence as a complete and independent legal system. ${ }^{5}$ There was also in existence a separate, independent and organized dispute resolution system based on the individual customary law of each community. This system of dispute resolution is generally referred to as customary arbitration and customary arbitration tribunals constituted by elders of that community administer it. The tribunals derive their authority from the custom and tradition of the community, which are accepted by members as binding on them. ${ }^{6}$ Customary arbitration is also recognized under Nigerian law as a valid dispute resolution mechanism. ${ }^{7}$

The arrival of the British colonialists in the 19 th century had a radical impact on the hitherto existing system of customary dispute resolution. ${ }^{8}$ They came with their own strange judicial system and dispute resolution mechanism. The process of colonization did not replace the practice of dispute resolution through arbitration in the local communities, as customary arbitration is still one of the modes of resolving disputes in contemporary indigenous communities of Nigeria. ${ }^{9}$ Igbokwe notes that:

The British colonization of Nigeria witnessed the interaction of English law with customary law. But the British colonization did not result in complete obliteration of the customary laws of Nigeria

3 Gadzama J.K, "Inception of ADR and Arbitration in Nigeria”. Paper presented at NBA conference Abuja, 2004 Dele P., What is Alternative Dispute Resolution? (Dee Sege Nigeria Limited Lagos, 2005) 11; Idornigie P.O. 'Overview of ADR in Nigeria'Arbitration (2007) Vol. 73 No 1, 73; Akanbi M. M. 'Constitutionality of Customary Arbitration in Nigeria - An Appraisal of Okpuruwu v. Okpokam (n 2) 1; See also Agwu v. Ikewibe (1991) 3 NWLR (pt. 180 ) 385.

4 Umeche C.I. "Customary arbitration and the Plea of Estoppel Under Nigerian Law” (2009) (35) 2 Commonwealth Law Bulletin 293.

5 Oba, A.A (n 2) 140.

6 Umeche C.I (n 4) 291; Akanbi M.M, “A Critical Assessment of the History and Law of Domestic Arbitration in Nigeria: Trends in Nigeria Law” in Oluduro et al (eds.), Essays in Honour of Oba DVF Olateru-Olagbegi III, Olowo of Owo Kingdom (Constellation Nig. Publishers) 462.

7 Okoye v Obiaso (2010) 8 NWLR (Pt. 1195) 145, 171-172; Achorv. Adejob (2010) 6 NWLR (Pt.1191) 537, 569; Okereke v. Nwanko (2003) 9 NWLR (Pt. 826) 592; Egesimbe v. Onwuzurike (2002) 15 NWLR (pt. 791) 446; Agu v. Ikewibe (1991) 3 NWLR (Pt.178) 385; Idika v. Erisi (1988) 2 NWLR (Pt. 78) 563.

8 ibid.

9 Idornigie P.O. “Overview of ADR in Nigeria” (n 2). 
and the local level dispute resolution mechanism such as customary arbitration. ${ }^{10}$

The judicial system, introduced by the colonialists, however gained superiority over traditional judicial systems, and customary law became only enforceable on their terms and parameters. ${ }^{11}$ This state of affairs dealt a fatal blow to customary arbitration, as a customary arbitral award would not be binding and enforceable if it is not in tandem with the parameters laid down by the courts.

More significant to this article is the philosophy and essence of arbitration under both laws. Arbitration under the common law is rigid and strictly contractual based on agreement of the parties. This is unlike customary law of indigenous Nigerian society, which is highly flexible. Customary arbitration is mainly to ensure peace and order in the society and also to preserve existing relationships. The philosophy and essence of practice of arbitration under both systems therefore fundamentally differs. Moreover, there is no single customary law in Nigeria. Customary law differs from society to society. It is, therefore, astonishing to see general rules being laid down for the validity of customary arbitral awards based on the superimposed common law features of arbitration.

This article reviews extant judicial parameters for the validity of customary arbitration and argues that most of the parameters are a derivative of practices of arbitration under common law. The article restates the effect of trying to lay down a general parameter for the validity of customary arbitration in Nigeria and thus advocates a re-assessment by the courts of their position on these parameters.

\section{OVERVIEW OF CUSTOMARY ARBITRATION PRACTICES IN NIGERIA}

Customary arbitration was in existence before the coming of the colonialists. As noted earlier, customary arbitration was, prior to colonial rule, an effective system of dispute resolution that was adaptable to the individual circumstances of local communities. This practice grounded

10 Igbokwe V.C. (n 2) 201.

11 See generally Tobi N, Sources of Nigerian Law (MIJ Professional Publishers, Lagos 1996); Obilade A. O. The Nigerian Legal System (Spectrum Books Ltd, Ibadan, 1979). 
in the customs and tradition of the people still exists to this day. It still forms part of Nigerian jurisprudence. ${ }^{12}$ This section appraises the practices of customary arbitration in various communities in Nigeria to show how deeply entrenched and properly organised it is. For the purpose of discussions on this section, practice of customary arbitration will be divided into two major regions: northern and southern regions. ${ }^{13}$

In northern Nigeria, the principal customary law prevailing in the predominately Muslim community is Islamic Customary law, ${ }^{14}$ which is in line with Sharia Law. ${ }^{15}$ The system of dispute resolution is also structured according to Islamic law. In northern Nigeria, emirs head Emirates. Each emir had a court even though they do not wield judicial power in most circumstances. Judicial power is usually wielded by the Alkali who administers Sharia law. ${ }^{16}$ The practice of arbitration under the Maliki School of Islamic jurisprudence applicable in Northern Nigeria

12 Idornigie P.O. (n 2) 73.

13 This is because northern and southern practice of arbitration fairly captures the divergence of customary arbitration practices in Nigeria. This, it is submitted, is by no means an all-encompassing account of how customary arbitration is practised in Nigeria.

14 Even though there have been a lot of controversies among scholars as to whether Islamic law is customary law. Oba opines that Islamic law is a divine law and cannot be considered as customary law, which is largely a man-made law. See Oba A.A 'Islamic Law as Customary Law: The Changing Perspective in Nigeria' The International and Comparative Law quarterly 51 (4), 817-850; Aboki Y. “Does Customary Law Include Islamic Law?" in Okoh, Alubo et al (eds.), Contemporary Frontiers in Nigerian Law: Essays in Honour of the Honourable Justice Salibu Modibbo Alfa Belgore (Oracle Business Ltd, Makurdi Nigeria 2006). Ladipo disagrees with the opinion of the above scholars and submits that Islamic Law is part of customary law because some of the sources of Islamic law are the Pre-seventh century Arabian customs, which are mainly man-made and also the continuing dynamism of the Sharia. See Ladipo, O.A. "Where does Islamic Arbitration fit into the Judicially Recognized Ingredients of Customary Arbitration in the Nigerian Jurisprudence?” (2008) Vol. 8, No 2 African Journal on Conflict Resolution 108, also available online at <www.ajol.info/index.php/ ajcr/article/viewFile/39427/59591> accessed 25 September 2012

15 The Sharia is the Muslim legal code. The Primary sources of the Shariah are the Quran, the Sunnah (Practice of the Holy Prophet), the Qiyas (analogical deductions) and Ijma (Consensus of Islamic Jurists). See Yusuf, Nigerian Legal System (National Publishing House, New Delhi 1982) 27, 33. In non-Muslim areas of the north, the practice of arbitration is similar to what is obtainable in the southern part of Nigeria. See Keay and Richardson, The Native and Customary Courts of Nigeria (Sweet \& Maxwell, London 1966) 21.

16 Yusuf A (n 15) 36. 
is known as Tabkim, which is based on the injunction of the Holy Quran encouraging the use of arbitration to settle disputes. ${ }^{17}$ Arbitration also finds support under the Sunnah of the Holy Prophet. ${ }^{18}$

The above does not mean that Islamic law system of arbitration is exclusively adopted in all areas of the North. For example, in Ilorin, ${ }^{19}$ the Daudus (district heads), Magaji, ${ }^{20}$ Alangu $^{21}$ and family heads still perform the function of arbitrators within their respective domain. ${ }^{22}$ The role played by these members of the community in resolving disputes among their subjects is not only a practice but a significant element of customary law: peaceful and harmonious resolution of dispute to ensure a continued peaceful co-existence among the people as well as the maintenance of social equilibrium of the society as a corporate whole. ${ }^{23}$ So is the practice of arbitration in northern Nigeria.

In the southern part of Nigeria, however, the practice of arbitration is more pronounced. This fact is highlighted by the number of litigated cases on customary arbitration from that part of the region. The method of dispute resolution still varies considerably in communities within the southern region, however, dispute resolution through arbitration are generally done by elders, family heads, and chiefs. ${ }^{24}$

There are principally two types of traditional societies in southern Nigeria: the cephalous society that has a central authority like the kings and emperor and the acephalous society, which has a decentralized system of government but controlled through collective leadership. The latter

17 See Quran Chapter 49 verses 9-10 and Quran 4 verse 35 and 58.

18 There were at least 3 instances where the Holy Prophet was involved in arbitration. He was said to have appointed an arbitrator, submitted to the decision of an arbitrator and was bound by an arbitral award. And He has also recommended the use of arbitration to others. See Abdulhamid El-Ahdab, Arbitration with the Arab Countries (2nd ed., Kluwer Law International, Hague 1999).

19 Ilorin is an ancient city and now capital of Kwara State of Nigeria. See Daibu A. A. "An Examination of the Rules of Natural Justice and Equal Treatment of Parties in Arbitration” (LL.M Thesis, Faculty of Law, University of Ilorin, 2012) 103.

20 Community Head.

21 Village Head.

22 Daibu A. A (n 19) 103.

23 Igbokwe V.C. "Socio Cultural Dimensions of Dispute Resolution: Informal Justice Processes among the Igbo speaking people of Eastern Nigeria and their implications for community/Neighbouring Justice System in North America” (1998) Vol. 10 (3) Africa Journal of International and Comparative Law 1.

24 ibid. 
are predominantly found in the eastern part of Nigeria. ${ }^{25}$ In the cephalous society, the king or emperor ${ }^{26}$ plays the role of final arbiter in any dispute arising within their domain. ${ }^{27}$ The role of the arbitrator in most cases is delegated to lesser chiefs within the kingdom or heads of families. ${ }^{28}$ The decisions of these lesser chiefs are however subject to the king's court if the need arises. ${ }^{29}$ On the other hand, in the acephalous society, the administrative machinery is diffused and disputes are normally resolved through a political arrangement whereby authority is wielded either by reason of headship of a very important and powerful family or clan or by being the oldest in the community. ${ }^{30}$ The essence of the exercise of this function by elders in various communities lies in the philosophy that these respected members are vast in the customary law of their communities. Thus, customary arbitration ensures harmonious settlement, stabilities, and most importantly, the maintenance of social equilibrium within the community.

This segment of the article has shown that the practice of customary arbitration varies from community to community even in areas within the same region. Each native society has a unique way of administration of justice, which is well suited to their individual local circumstances and worked perfectly well for them. The courts in Nigeria also see customary law as one, with same qualities and characteristics. This has not done well to the practice of customary arbitration.

25 Akanbi M.M. "A Critical Assessment of the History and law of Domestic Arbitration in Nigeria” (3rd ed The Learned, Law Students' Association Kwara State College of Arabic and Islamic Legal Studies Ilorin) 40-41.

26 Traditional kings are called "Emir" in the Northern part of Nigeria save for the Sultan of Sokoto whose traditional title is "Sultan"; virtually all traditional kings in the north are Emir. In the South-Western part of Nigeria traditional kings are generally referred to as $\mathrm{Oba}$ although with different tittles e.g. The Alafin of Oyo, Oni of Ife, Oba of Benin, Oba of Lagos, Olubadan of Ibadan, Alake of Egba and Timi of Ede to mention a few. See Daibu A. A (n 19) 104

27 Akanbi M.M. (n 25) 41.

28 Oluduro, O. (n 2) 13.

29 The king's Court serves as Appellate Court, which can review the decision of the family heads, elders and chiefs at the instance of one of the parties. See Akpata E, The Nigerian Arbitration Law in Focus (n 2)1, for an example in Benin Kingdom in the southern part of Nigeria.

30 Emiola A, The principle of African customary law (Emiola Pub Nig. 1997) p .1; Igbokwe V.C. Dispute settlement among Ibo and community Justice in North America P. 451; Akanbi M.M. (n 25) 41. 


\section{CONCEPT AND PHILOSOPHY OF CUSTOMARY ARBITRATION}

The concept of arbitration under customary law fundamentally differs from arbitration in western societies. The point of dichotomy is more apparent based on two broad factors, to wit: concept of law and justice, and philosophy and purpose of arbitration in both societies. ${ }^{31}$ The concept of law and justice in the indigenous societies of Nigeria is deeply rooted in the community. The interest of the community in general prevails over the interest of individuals, ${ }^{32}$ so also the experience of the community as a clearly bounded group strongly outweighs the experience of ego-centred networks of personal relationships. ${ }^{33}$ The stability and continued existence of the group is a much more important consideration than the rights of individuals. ${ }^{34}$ This position can also be said of the Islamic law, which is the predominant law applicable in northern indigenous societies of Nigeria. The concept of law and justice under Islamic law is based on mutual respect between persons. ${ }^{35}$ Under this law, the larger interest of the society takes precedence over the interest of the individuals. ${ }^{36}$ It is thus submitted that the concept of law and justice under indigenous Nigerian society are similar to those of Islamic Law and have little in common with that in the western societies.

However, the concept of law and justice in western societies is based on the principle of individualism which allows for party autonomy so long as the interest of others are not unduly affected and the public good is not unduly threatened. ${ }^{37}$ In western societies, private agreements are regarded as sacred and must be enforceable no matter the circumstance. The state does not concern itself with the private arrangements of individuals. In fact, individuals are free to exclude the state from their

31 Akanbi M.M. Domestic Commercial Arbitration in Nigeria: Problems and Challenges (Lambert Academic Publishing: Germany, 2012) p. 113.

32 ibid.

33 ibid.

34 ibid.

35 Doi A. Sharia: The Islamic Law (Iksan Islamic Publishers, Nigeria 1990) 8.

36 ibid, 11.

37 Dalhuisen J. H, Dalbuisen on International Commercial Financial and Trade Law (2nd, Hart Publishing, Oregon 2004) p. 112. 
private affairs. The intervention of the state, if any at all, is minimal..$^{38}$ The interest of the general public or the community is of secondary importance. ${ }^{39}$

The essential philosophy of arbitration in indigenous Nigerian societies is that it is a system of governance for the social order, and the maintenance of peace and stability in the community. ${ }^{40}$ The process of arbitration as a dispute resolution mechanism is viewed as a continuation of the control of affairs of the individual by the society in order to ensure the promotion of a stable and harmonious society, ${ }^{41}$ while the essence of arbitration in western society is the promotion of party autonomy and the reduction of state interference. Thus, the growth and practice of arbitration as a dispute resolution mechanism is tailored according to the "contractual concept". ${ }^{42}$

Arbitration is always regarded as a contract with a sacred obligation to fulfil its terms. The process of arbitration is mainly as an instrument of free flow of commerce; hence there is little or no interference by the state. The essence of arbitration under Islamic $\operatorname{law}^{43}$ seems to be similar to that obtainable under modern arbitration, as arbitration is treated as a contract with a sacred obligation to fulfil its agreed terms. ${ }^{44}$ Thus, it is submitted that it differs fundamentally from the western philosophy because its purpose is to mend relationship between feuding parties and ensure preservation of existing relationship between the parties.

The challenge of imposing the features of customary arbitration of a society on another has serious implications as the philosophy and essence of arbitration in both societies may fundamentally differ. It is thus

38 Elombi, G. “Arbitration of International Commercial and Investment Disputes: Are the Misgiving of Developing States Justifies?” (Ph.D Thesis, Queen Mary \& Westfield College, University of London1996) 85.

39 Ibid.

40 Akanbi, M.M. "A Critical Assessment of the History and law of Domestic Arbitration in Nigeria” The Learned 3rd edition (Law Students' Association Kwara State College of Arabic and Islamic Legal Studies Ilorin) 41.

41 Ibid, 139.

42 Akanbi M.M. Domestic Commercial Arbitration in Nigeria: Problems and Challenges (Lambert Academic Publishing: Germany, 2012)136.

43 Especially Under the Maliki School of Shariah Practiced in Nigeria. Alkamawa v. Bello (1998) 8 NWLR [Pt 561] 173; see also Obilade A.O Nigerian Legal System (Spectrum Books Limited, Ibadan 1979) 83.

44 Khadduri M. The Islamic Conception of Justice (The John Hopkins Press Ltd., London 1984) 141. 
imperative to consider the issue of the legality of customary arbitration in Nigeria.

\section{LEGAL STATUS OF CUSTOMARY ARBITRATION IN NIGERIA AND APPLICABLE ISSUES}

The legal status of customary arbitration as a dispute resolution mechanism has gone through a tortuous journey in the Nigerian courts from its initial acceptance to its denial to a reconfirmation of its validity as an authentic dispute resolution mechanism under Nigerian jurisprudence. ${ }^{45}$ From the outset, the practice of dispute resolution by elders of the community has been recognized under Nigerian Jurisprudence. In Assampong v. Amuaku ${ }^{46}$ the West African Court of Appeal (WACA) held that:

... where matters in dispute between parties are, by mutual consent investigated by the arbitrators at a meeting held in accordance with native law and custom and a decision given, it is binding on the parties and the Supreme Court will enforce such decision. ${ }^{47}$

Other decisions of the court (though of Ghanaian origin) follow that line of thought, by holding that the practice of elders handing down binding and enforceable award is recognized under the law. ${ }^{48}$ The Nigerian courts too towed that line in cases such as Inyang v. Essien, ${ }^{49} \mathrm{Njokwu} v$. Felix ${ }^{50}$ and Idika v. Esiri. ${ }^{51}$ Surprisingly, the validity of customary arbitration was denied in the case of Okpuruwu v. Okpokam ${ }^{52}$ where Uwaifo JCA held that:

I do not know of any community in Nigeria, which regards the settlement by arbitration between disputing parties as part of native

45 Ladipo O.A. “Where does Islamic Arbitration fit into the Judicially Recognized Ingredients of Customary Arbitration in the Nigerian Jurisprudence?” (2008) 8 (2) African Journal on Conflict Resolution 104 [Ladipo].

46 (1932) 1 WACA.192.

47 Ibid at 201.

48 Foli v. Akese (1930) 1 WACA P.1; Kwasi v. Larbe (1952) 13 WACA p. 76.

49 (1957) 2 FSC 39.

50 (1972) 2 ECSLR 90.

51 (1988) 2 NWLR [Pt 90] 572.

52 (1988) 4 NWLR (Pt. 90) 554. 
law and custom. It may be that in practical life, when there is a dispute in any community, the parties involved may sometimes decide to refer it to disinterested third party for settlement. That seems more of a common device for peace and good neighbourliness rather than a feature of native law and custom...I do not also know how such a custom, if any, or more correctly, such practice, to get a third party to intervene and decide a dispute can elevate such a decision to the status of a judgment with binding force and yet fit into our judicial system... ${ }^{53}$

Arguably, the position taken by the learned jurist is rather novel and shocking especially because of the numerous decisions handed by the courts which recognized the validity of customary arbitration. ${ }^{54}$ Interestingly, Oguntade JCA, even though concurring with the lead judgment in the final analysis, was of a different opinion as to the validity of customary arbitration as a recognized indigenous method of dispute resolution in Nigeria. He disagreed with the opinion in the lead judgment that customary arbitration does not exist.

Fortunately, in 1991, there was an opportunity for the courts (and this time, the Supreme Court) to pronounce on the legal status of customary arbitration. This was an avenue to set the record straight. ${ }^{55} \mathrm{In}$ Agu v. Ikewibe ${ }^{56}$ the Supreme Court per Karibi-Whyte JSC held that:

It is well accepted that one of the many African customary modes of settling dispute is to refer the dispute to the family head or an elder or elders of the community for a compromise solution based upon the subsequent acceptance by both parties of the suggested award, which either party is free to resile at any stage of the proceedings up to that point. This is a common method of settling disputes in all indigenous Nigerian societies.

It is now settled that customary arbitration is one of the methods of resolving disputes in Nigeria. It derives its validity from customary law of the indigenous community and by extension the constitution of

53 Ibid, at p. 571-574.

54 Ladipo, 104.

55 Igbokwe V.C. 'Law and Practice of Customary Arbitration in Nigeria: Agu V. Ikewibe and Applicable Law Issues Revisited' (1997) 41 (2) Journal of African Law 205 [Igbokwe].

56 (1991) 3 NWLR (Pt. 180) 385. 
Nigeria. ${ }^{57}$ Sections 315(3) and (4)(b) of the Constitution of the Federal Republic of Nigeria, 1999 (as amended) recognizes customary law as an "existing law" and by implication upholds the validity of customary arbitration since it is derived from customary law. The valid status of customary arbitration has been given further impetus by the Arbitration and Conciliation Act. ${ }^{58}$ Section 35 (b) of the Act acknowledges arbitration "in accordance with the provisions of other laws." ${ }^{59}$ It is submitted that arbitration in accordance with the provisions of other laws contemplates customary arbitration. ${ }^{60}$ Recent decisions of the court further vindicate the existence and binding character of customary arbitration. ${ }^{61}$

\section{REVIEW OF THE JUDICIAL PARAMETERS FOR THE VALIDITY OF CUSTOMARY ARBITRATION IN NIGERIA}

Even though the issue of the existence and validity of customary arbitration under Nigerian jurisprudence appears settled, what appears contentious are the parameters for determining the validity of a customary arbitral award. ${ }^{62}$ Customary arbitration awards are usually expressed to be "conclusive and unimpeachable." ${ }^{63}$ The awards are also binding and enforceable. This is the position of the law provided certain criteria or parameters (evolved by the modern courts) for the validity of customary arbitration are satisfied. ${ }^{64}$

57 Akanbi M.M. Domestic Commercial Arbitration in Nigeria: Problems and Challenges (Lambert Academic Publishing: Germany, 2012)22.

58 Cap A18 Laws of the Federation of Nigeria 2004.

59 S35 provides that "this Act shall not affect any other law by virtue of which certain disputes"...(b) may be submitted to arbitration only in accordance with the provisions of that or another law"

60 Igbokwe, 206.

61 Okoye v Obiaso (2010) 8 NWLR (Pt. 1195) 145 at 171-172; Achor v. Adejob (2010) 6 NWLR (Pt.1191) 537 at 569; Ieka v. Tyo (2007) 11 NWLR [Pt 1045] 385 at 389 .

62 Igbokwe, 201; Elombi, G. "Arbitration of International Commercial and Investment Disputes: Are the Misgiving of Developing States Justifies?” (Ph.D Thesis, Queen Mary \& Westfield College, University of London1996) 803.

63 Unless such customary award is being set aside on any of the recognized ground such as the inability of the award to satisfy the yardsticks laid out by modern courts see Achor v. Adejob (2010) 6 NWLR [part 1191] 537 at 569.

$64 \mathrm{Oba}$ A.A. "Juju Oath in Customary Arbitration and Their Legal Validity in Nigerian Courts' Journal of African Law (2008) Vol. 52 No.1 p. 142. 
The Nigerian courts have not been consistent in stating the essential ingredients of a valid customary arbitration. ${ }^{65}$ Various decisions emanating from courts on these criteria present conflicting and confusing scenario. Interestingly, members of the same panel in some cases do not come to a consensus on these parameters. ${ }^{66}$ This uncertainty has affected the practice of customary arbitration in several ways.

In Awonusi v. Awonusi, ${ }^{67}$ Okoro JCA after reviewing previous cases stated that:

Four ingredients usually accepted as constituting the essential characteristics of a binding arbitration are:

(i) Voluntary submission of the dispute to the arbitration of the individual or body

(ii) Agreement by the parties either expressly or by implication that the decision of the arbitrators will be accepted and binding

(iii) That the arbitration was in accordance with the custom of the parties; and

(iv) That the arbitrators reached a decision and published their award.

The court did not consider the acceptance of the decision by the parties after the award has been made as part of the criteria. ${ }^{68}$ However, in Achor v. Adejob ${ }^{69}$ the same Court of Appeal (Abuja judicial Division) per Aboki JCA held that a valid arbitration must consist of the following:

(a) Submission of both parties to the arbitration

(b) The arbitration must be recognized by both parties; and

(c) The parties must agree to be bound by the decision.

Similarly, in Okoye v Obiaso, ${ }^{70}$ the Supreme Court stated that a party can prove the existence of customary arbitration by pleading and

65 Ladipo, 104, 113.

66 A typical example is in the case of Egesimba v. Onuzuike (2002) 15 NWLR [Pt. 791] 466 where the lead judgment (Per Ayoola JSC), the concurring judgment (Per Ogundare JSC) and the dissenting opinion (Per Niki Tobi JSC) all set out three different sets of yardsticks for the validity of customary arbitration awards. 67 (2007) All FWLR 1642 at 1662.

68 In fact, the court expressly rejected that condition by saying that it "would be repugnant to good sense and equity to allow a losing party to reject or resile from the decision of the arbitrators to which he had previously agreed". See page 1657 69 Supra at page 590.

70 (2010) 8 NWLR Part 1195 page 145 at 171. 
establishing the following:

(a) That there has been a voluntary submission of the matter in dispute to an arbitration of one or more persons.

(b) That it was agreed by the parties either expressly or by implication that the decision of the arbitrators will be accepted as final and binding.

(c) That the said arbitration was in accordance with the custom of the parties or of their trade or business.

(d) That the arbitrators reached a decision and published their award; and

(e) That the decision or award was accepted at the time it was made.

The above captures clearly the inconsistency of the courts on the criteria for the validity of customary arbitration. A review of judicial decisions right from pre-independence era to decision of Supreme Court in the 21 st century shows the prevalence of seven criteria, to wit: acceptance of the award by the parties; voluntary submission by the parties to arbitration; submission to bodies or persons recognized as having judicial authority under the custom of the parties; agreement by the parties beforehand to be bound by the decision of the arbitral tribunal; conduct of the arbitral proceedings in accordance with the custom of the parties; non-withdrawal of any party before publication of the award by the arbitral tribunal and publication of the award. ${ }^{71}$

For the purpose of consideration of the criteria, those laid down in the case of Agu v. Ikewibe, ${ }^{72}$ would form the subject of consideration. Before discussing each of the criteria in turn, one important issue, which must be addressed, is whether or not these criteria must all exist at a particular time before a customary arbitration award is upheld as valid by the court. In other words, do these criteria operate concurrently? It will appear that the criteria do not concurrently operate, especially because there is no consensus on them by the courts. However, it is submitted that all the criteria laid down in a particular decision must all exist, for that award to be upheld. This means that the criteria laid down in a particular decision must all exist concurrently. In Duruaku Eke E Ors v. Udeozor Okwaranyiai E Ors, the Supreme Court per Uwaifo JSC, after laying down the judicial parameter went ahead to state:

71 Ladipo, 115.

72 Supra. 
I think anything short of these conditions will make any customary arbitration award risky to enforce. In fact, it is better to say that unless the conditions are fulfilled, the arbitrations award is unenforceable. ${ }^{73}$

The use of the word "must" in most of the decisions laying down these criteria is a vindication of our position. ${ }^{74}$ This state of affairs, as will be argued later, has caused too much trouble to the operation and practice of customary arbitration in Nigeria as a viable dispute resolution mechanism in Nigeria.

\subsection{Voluntary Submission}

Voluntary submission has been said to be the basis of arbitration and it is universal to the concept of arbitration under all legal systems. ${ }^{75}$ Akanbi opined that while this might be true for the western type arbitration it is doubtful if the same can be said for customary arbitration as customary arbitration is not founded on the basis of contract or commerce but rather it evolved as a social device for the maintenance of a stable and harmonious society. ${ }^{76}$

The word "voluntary”, as defined by the Black's Law Dictionary, is something "done by design or intention." 77 Voluntary submission implies that a party entered into the arbitration agreement based on his own free will without any external influence or force whatsoever. It is submitted that the requirement of voluntary submission is akin to the common law system of arbitration, which regards private agreement entered into freely by parties as sacred.

The position of voluntary submission under customary arbitration is a bit dicey and that is why some scholars argue that customary arbitration has more of the features of litigation than arbitration properly so called. A typical customary arbitral process in most Nigerian societies starts with a complaint by an aggrieved party to the appropriate authority

73 Ibid.

74 See Agala v. Okusin (2010) 10 NWLR (Pt 1202) 412 at 448 where Ogbuagu JSC use the word "must" for each of the yardsticks.

75 Ladipo, 115.

76 Akanbi M.M. Domestic Commercial Arbitration in Nigeria: Problems and Challenges (Lambert Academic Publishing: Germany, 2012)151.

77 Black's law dictionary (8th edition) 1605. 
after which the other party is summoned or invited. ${ }^{78}$ The question thus is: "can a submission after a summons be termed voluntary submission?" It is submitted that the requirement of voluntary submission is an attempt by the courts to lay down a general rule for customary arbitration based on borrowed western principle of arbitration and that will have negative impact on the practice of customary arbitration in Nigeria.

\subsection{Submission to Bodies or Persons Recognized as Having Judicial Authority Under the Custom of the Parties}

This requirement was brought to limelight in the case of Inyang v. Essien, ${ }^{79}$ For a customary arbitral award to be upheld by the court, the tribunal must be a body of persons having judicial authority. The question then is what group of body could be said to wield "judicial authority"? This requirement seems to be very vague and that could be a reason why it is not contained in many of the recent decisions on the parameters of customary arbitration. ${ }^{80}$ Unfortunately, the courts in some other cases have continued to pronounce that submission to elders or chiefs is a requirement for the validity of customary arbitration. It is humbly submitted that the same problem of generalization of the criteria still applies here. In clear term, Ladipo submits that:

With respect, it is posited that this position is a generalization, which is incongruous with the facts and realities of some arbitral customs. This is particularly the case in arbitrations based on oath taking before priests, arbitrations before age groups, women's groups, trade and business groups. The tribunals in the foregoing arbitral customs are obviously not constituted of elders and chiefs. ${ }^{81}$

\subsection{Prior Agreement to be Bound by the Arbitrator's Award}

This criterion is fundamental to the validity of an arbitral award under English arbitration. However, it is submitted that this criterion, which was borrowed from the English common law system has now been made

78 Emiola A, The Principles of African Customary Law (Emiola Pub, Nigeria 1997) pp. 37, 38.

79 (1977) NSCC p. 464.

8o Achorv. Adejob (2010) 6 NWLR (Pt.1191) 537 at 569; Okereke v. Nwanko (2003) 9 NWLR (Pt. 826) 592; Egesimbe v. Onwuzurike (2002) 15 NWLR (pt. 791).

81 Ladipo, 119. 
a requirement for customary arbitration. English arbitration is strictly contractual, based on agreement of both parties. The criterion is inextricably connected with the requirement of voluntary submission. ${ }^{82}$

\subsection{Conduct of Arbitration in Accordance with the Customs of the Parties}

This seems to be the most fundamental of all the extant criteria for the validity of a customary arbitral award. Customary arbitration must be in accordance with the customs and tradition of the particular society in question. An attempt to lay down borrowed criteria will be fatal to the practice of customary arbitration in Nigeria.

\subsection{Non-withdrawal of Any Party Before the Publication of the Award}

This criterion will be considered elaborately when discussing the last requirement as regards points at which parties can resile as the two conditions are connected.

\subsection{Publication of the Award}

When discussing publication of an award as one of the parameters for the validity of a customary arbitration award, two things that come to mind are: first, the award must be declared publicly. However, this is antithetical to the spirit of customary arbitration as one of the main reasons parties resort to arbitration for the settlement of their disputes is to ensure privacy and confidentiality. Indeed, confidentiality has been identified as one of the major potentials of an ADR process. ${ }^{83}$ The second thing that comes to mind is that the award must be in a written form. This condition seems impracticable especially because of the largely unwritten and unsophisticated nature of customary law. The requirement of publication of customary arbitral award, means the act of conveying an arbitration award to the parties.

82 Ibid, 120.

83 Akanbi M. M. "Kwara Multidoor House: An Idea Whose Time Has Come.” A paper delivered on the occasion of the formal inauguration of the Committee on the proposed Kwara State Multidoor Courthouse at the High Court of Kwara State on Tuesday, 29 July 2008. 


\subsection{Acceptance of the Award at the Time it Was Made}

Acceptance of the award at the time it was made indicates that none of the parties must have withdrawn from the arbitration after the award was made. Consequently, a party is free to reject an award he finds unfavourable by this parameter. This criterion appears to be the most controversial and unsettled among all the criteria. ${ }^{84} \mathrm{Oba}^{85}$ submits that the criterion was introduced in the case of Aguv Ikewibe $e^{86}$ where the court after a review of previous decisions on the subject matter, quoted Elias to the effect that arbitration is a mode of:

... referring a dispute to the family head or an elder of the community for a compromise solution based upon subsequent acceptance by both parties of the suggested award, which becomes binding only after such signification of its acceptance and from which either party is free to resile at any stage of the proceedings up to that point.

By the above decision, parties to arbitration have an unfettered right to reject an unfavourable award. The decision has generated heated controversy among jurists and scholars alike. Some opine that the decision is not in tandem with previous decisions on the subject matter, as allowing a party to freely resile out of a valid arbitral award for which he has previously agreed to be bound is contrary to good sense and equity. ${ }^{87}$ They further submitted that the submission of Elias relied upon was quoted out of context. ${ }^{88}$ Particularly, Ezejiofor criticized the decision and submits that this condition and the other conditions listed by the Supreme Court may not be consistent with customary practices of a particular

84 The Supreme Court has in some cases ignored the requirement. See Egesimba v. Onzuruike (2002) 9 SCNJ 46 where the court did not consider post award consent as a condition.

85 Oba A.A. "Juju Oath in Customary Arbitration and Their Legal Validity in Nigerian Courts" (2008) 52 (1) Journal of African Law 143.

86 Supra.

87 A. L. Okekeifere "The recent odyssey of customary law arbitration and conciliation in Nigeria's apex court” (2002) 4/1 Modern Practice Journal of Finance and Investment Law 113-117

88 Oba submits that the supreme court left out the question mark at the end of the above quoted decision that the part of the decision emphasised was meant to be a question for which Elias answer was it seems also that neither party can lawfully resile after the award has been made. 
community. ${ }^{89}$ They posited that Nigeria is a country with various customs and the determinants of the conditions should be the customary law of the community under consideration.

Recent decisions of the courts are in support of the opinion of the learned scholars above. In Awonusi $v$ Awonusi, ${ }^{90}$ a dispute relating to a family land, the appellants initiated customary arbitral proceedings before the Ewusi-in council, a traditional customary arbitrator where the dispute was heard and determined. The appellant as defendants at the lower court thereafter sort to resile by refusing to abide by the decision of the council. The respondent as plaintiff before the lower court instituted an action at the High Court. The High Court granted all his claims. The appellant subsequently appealed to the court of appeal. Dismissing the appeal, Fabiyi JCA (as he then was) held that:

Where arbitration under customary law is pronounced valid and binding, it would be repugnant to good sense and equity to allow the losing party to reject or resile from the decision of the arbitrators to which he has previously agreed. ${ }^{91}$

By the above decision and a host of several others following that line of reasoning, parties are not free to resile from a validly handed arbitral award.

With due respect, this paper disagrees with the above opinion of the learned justice and agrees with the learned scholars above, only to the extent that the parameters for determining the validity of customary arbitration should be dictated by the particular customs and tradition of the community and not based on parameters formulated by the courts. It is submitted that the courts are just attempting to lay down general parameters for the validity of customary arbitration and that will do no good to the practice of customary arbitration. The fact that parties may be allowed to resile in one community does not necessarily mean the parties could do so in another community. For instance, a party cannot back out of arbitration under Islamic law, which is largely adopted by

89 Ezejiofor, G. “The Pre-requisites of customary arbitration” (1992-93) 16-18. Journal of Private and Property Law 1.

90 supra.

91 supra, 1657. 
communities in northern Nigeria. ${ }^{92}$ This is may not be applicable in the eastern or western part of Nigeria.

To lay down a general rule that parties cannot resile from an arbitral award is in a way trying to import the British common law system of arbitration, which sees arbitration, as strictly a contract for which parties are bound and cannot back out at will. This may not be in conformity with the customs and tradition of the indigenous people whose idea of arbitration is not only a mechanism to ensure smooth running of the system but to also ensure that peace and a good relation is maintained in the society. This runs contrary to the philosophy of arbitration under customary law.

There is no doubt that the Nigerian courts are attempting to formulate general principles or criteria for the validity of a customary arbitration award and this has done nothing but create more difficulty to the practice of customary arbitration in Nigeria.

\section{CUSTOMARY ARBITRATION: JUDICIAL PARAMETERS AND THE NEED FOR A PARADIGM SHIFT}

The British system of administration of justice is sophisticated and complex and so is their system of adjudication and arbitration. The nature, philosophy and essence of arbitration under the common law fundamentally differ from arbitration under customary law. Arbitration under the common law is contractual. Agreements between parties are seen as sacred and must be upheld at all times. Furthermore, the British operate based on an individualistic philosophy. The interest of the individual supersedes the interest of the community at all times. This is unlike the native society in Nigeria.

The system of administration of justice in native communities in Nigeria is very simple and unsophisticated. Their idea of arbitration is that it is an instrument used to ensure peace and good neighbourliness and also to ensure the continuance of friendly relations in the community. Thus, an attempt to smuggle in the parameters for the validity of arbitration under common law has affected the practice of customary law in Nigeria.

92 Sahcht, J. An Introduction to Islamic Law (Clarendon Paperbacks, Oxford 1996) 10. 
Common law, as have been earlier identified, has a fixed and rigid feature. It has the characteristics of certainty. This is unlike our own customary law which is generally unwritten and not codified. It arises from the traditional rules governing the people as well as the opinions of text writers. ${ }^{93}$ Also, customary law in Nigeria has a very flexible nature, because of its unwritten characteristics; it is ever changing and can therefore be easily applied to particular situations at particular times. It is easily adaptable to changing circumstances. ${ }^{94}$

The problems encountered by customary arbitration in the face of the onerous and uncertain parameters established by the English styled courts calls for a radical change in the court's approach towards the validity of customary arbitration awards. One of the reasons for this paradigm shift is because there is no single customary law applicable to Nigeria. Various communities have their own different applicable customary practices, which are adaptable to their own individual community and are acceptable to them. This, by parity of reasoning implies that what is applicable to a particular community may not necessarily be applicable to another community and, as such, an attempt by the courts to lay down general principles or criteria for the validity of customary arbitration which is largely regulated by customary law, is an attempt to make customary law rigid. This is against the fundamental philosophy behind customary practices in Nigeria. The dispute settlement process of a particular social system is normally the sum of the peculiar circumstances of that particular community. ${ }^{95}$

The validity of customary arbitration must be based on individual customary practices in the various communities. What may be legally acceptable in Yoruba kingdom may not necessarily be acceptable in Benin Kingdom. The court must recognize this fact in the enforcement of customary awards. Enforcement mechanisms should not be divorced from the social relationship existing in a particular society. ${ }^{96}$

93 Tobi N Sources of Nigerian Law (MIJ Professional Publishers, Lagos, 1996) 108.

94 Lewis v. Bankole (1908) 1.N.L.R. 81; Kimdey and ors v. Military Governor of Gongola State and ors (1988) 2.NWLR. (Pt. 77) 461.

95 Quashigah E.K, "Reflections on the Judicial Process in Traditional Africa" (19891990) 4 Nig. Judicial Review 1.

96 Igbokwe, 301. 
It is impracticable to view Nigeria (like most African countries) as a single homogenous society ${ }^{97}$ it is socially and culturally fragmented. Shorter observes that:

... again, one cannot speak and write about Africa as if it were a single, homogeneous society, or even a series of isolated, ethnic groups, all basically similar or comparable. On the contrary, Africa is (and was) socially and culturally very fragmented indeed. To begin with, there are very diverse physical environments, to which the various human groups have adapted themselves economically and socially in relative isolation. Then, again, there has been no uniformity in these adaptations, but rather a multiplicity of independent traditions and inventions even in the same, or similar, environments. The different traditions and systems have, moreover, been modified in different ways, according to the impact of historic personalities and the historic contact between ethnic groups. The result is a bewildering variety of social and political systems, of languages, cultures and religions. ${ }^{98}$

\section{CONCLUSION}

The introduction of a modern system of dispute resolution and the establishment of regular court based on the English common law have, in many ways, hindered the traditional dispute resolution method. ${ }^{99}$ Customary arbitration offers disputants a dispute resolution method that is cheap, quick and, above all, more in tandem with their own individual local circumstance. It is more responsive to their yearnings and aspirations. It is suggested that once a customary arbitration award has passed the requirement for validity of customary law, it should be enforceable by the court. The requirement for the validity of customary law is that the law must not be repugnant to natural justice, equity and good conscience;

97 Akanbi, M.M. Domestic Commercial Arbitration in Nigeria: Problems and Challenges (Lambert Academic Publishing: Germany, 2012)119.

98 Shorter, A. "Concepts of Social Justice In Traditional Africa” in ATR Special Topics (Pro Dialogo Bulletin 12 (1977), 32-51.

99 Oluduro, O. "Customary Arbitration in Nigeria: History and Developments" in Kupolati T (ed.) Current Issues in Nigerian Jurisprudence Essays in Honour of Chief Adegboyega Solomon Awomolo SAN (Renaissance law Publishers, Lagos, 2007) 37. 
it must not be contrary to public policy ${ }^{100}$ and it must not be incompatible with a law being in force. ${ }^{101}$ Consequently, once a customary arbitration award is not repugnant to natural justice, equity and good conscience and it is not inconsistent with any law being in force, it should be upheld by the court. Furthermore, if the customary arbitration award passes the test of public policy, it should be upheld and enforced by the court. This, arguably, is a fair position.

100 Section 18(3) of Evidence Act Cap E 14 Laws of the Federation of Nigeria, 2011.

101 Section 27 (1) of the High Court Lagos Act Cap 80 Laws of the Federation and Lagos State. 